Abstracta Iranica Abstracta Iranica

Revue bibliographique pour le domaine irano-aryen

Volume 42-43 | 2021

Comptes rendus des publications de 2019-2020

\title{
Rudi Matthee. "Safavid Iran and the Christian Missionary Experience. Between Tolerance and Refutation"
}

\section{Denise Aigle}

\section{(2) OpenEdition}

Journals

Édition électronique

URL : https://journals.openedition.org/abstractairanica/52658

DOI : 10.4000/abstractairanica.52658

ISSN : 1961-960X

Éditeur :

CNRS (UMR 7528 Mondes iraniens et indiens), Éditions de l'IFRI

Référence électronique

Denise Aigle, «Rudi Matthee. "Safavid Iran and the Christian Missionary Experience. Between Tolerance and Refutation" », Abstracta Iranica [En ligne], Volume 42-43| 2021, document 2, mis en ligne le 15 avril 2021, consulté le 23 décembre 2022. URL : http://journals.openedition.org/abstractairanica/ 52658 ; DOI : https://doi.org/10.4000/abstractairanica.52658

Ce document a été généré automatiquement le 23 décembre 2022.

Tous droits réservés 


\title{
Rudi Matthee. "Safavid Iran and the Christian Missionary Experience. Between Tolerance and Refutation"
}

\author{
Denise Aigle
}

\section{RÉFÉRENCE}

Rudi Matthee. "Safavid Iran and the Christian Missionary Experience. Between

Tolerance and Refutation", Mélanges de l'Institut dominicain d'études orientales, vol. 35, 2020 (Dossier - Les interactions entre (šĩ ites imāmites et chrétiens), p. 65-100.

1 Dans cet article, R. Matthee étudie les interactions entre l'islam chiite et le christianisme dans l'Iran safavide. Les récits des voyageurs et des missionnaires occidentaux sont la source principale de son étude. Joseph Piton de Tournefort, pat exemple, témoigne du syncrétisme religieux à l'œuvre dans le Caucase où les musulmans en Géorgie font appel à des saints chrétiens géorgiens et des Arméniens qui prient des prophètes musulmans. L'une des premières manifestations de l'interaction entre chiisme et christianisme catholique se manifeste dans la convergence iconographique entre les deux religions. La vénération pour Marie est un des principaux traits de l'Iran safavide. Au début du XVI siècle, le voyageur portugais Nicolau de Orta Rebelo a vu des images peintes de Marie avec l'enfant Jésus dans le palais du gouverneur du Fārs à Chiraz. R. Matthee dit que les peintures européennes et les images pieuses faisaient partie des cadeaux apportés à Shāh 'Abbās par le voyageur portugais António de Gouvea en 1602. Le pouvoir émotif du symbolisme religieux a joué un rôle dans l'attrait de beaucoup de personnes pour le christianisme. En effet, islam chiite et christianisme partagent un certain nombre de figures et de thèmes narratifs. Le Christ, le dieu qui devin humain, a une forte ressemblance avec l'Imām 'Alī, qui tout en étant un humain, peut apparaître comme une forme d'incarnation du divin pour certains chiites. Beaucoup de voyageurs témoignent de la fascination des Iraniens pour l'iconographie chrétienne. Luis Pereira de Lacerda relate comment les musulmans 
fréquentaient le couvent augustin d'Ispahan et comment ils vénéraient les images des saints chrétiens et qu'ils les embrassaient avec respect. R. Matthee décrit aussi la convergence esthétique entre islam chiite et christianisme dans le style de peinture européanisé, le farangī-sāzī, qui a culminé pendant le règne de Shāh Sulaymān (r. 1077/1666-1105/1694). Ce courant esthétique européanisé avait débuté avec un petit groupe de peintres hollandais qui travaillaient à la cour royale. Cette iconographie s'exprimait en référence avec des figures de femmes célèbres de la Bible (Élisabeth, Marie Judith, Marie Madeleine), et plus particulièrement avec la Vierge Marie qui apparaît comme un substitut à l'image de Fāțima. Ensuite, R. Matthee s'interroge sur le rôle des missionnaires dans l'Iran safavide qui agissaient avec une certaine liberté. Il montre qu'ils pouvaient être utiles à la cour en tant qu'interprètes au moment des ambassades européennes. Les missionnaires étaient également populaires auprès des basses classes sociales pour les capacités thaumaturgiques que les gens leur attribuaient, ainsi qu'aux images pieuses. R. Matthee conclut en disant que les Iraniens (élites et peuple) étaient fascinés par le christianisme à cause de l'iconographie, du symbolisme religieux, de l'idée de sainteté, de la notion de retour, toutes ces thématiques avaient des similitudes avec le chiisme.

\section{AUTEURS}

DENISE AIGLE

UMR 8167 - Orient et Méditerranée 